\title{
Immunoglobulin-A (IgA) Improvement through Sports and Frirage Massage
}

\author{
Bambang Priyonoadi ${ }^{1}$, Japhet Ndayisenga ${ }^{2}$, Panggung Sutopo ${ }^{1}$, Ali Satia Graha ${ }^{1}$ \\ ${ }^{1}$ Department of Sport Science, Yogyakarta State University, Indonesia \\ ${ }^{2}$ University of Burundi, Institute of Physical Education and Sports Bujumbura, Burundi
}

Received July 12, 2020; Revised October 16, 2020; Accepted October 24, 2020

\section{Cite This Paper in the following Citation Styles}

(a): [1] Bambang Priyonoadi, Japhet Ndayisenga, Panggung Sutopo, Ali Satia Graha, "Immunoglobulin-A (IgA) Improvement through Sports and Frirage Massage," International Journal of Human Movement and Sports Sciences, Vol. 8, No. 5, pp. 271-282, 2020. DOI: 10.13189/saj.2020.080516

(b): Bambang Priyonoadi, Japhet Ndayisenga, Panggung Sutopo, Ali Satia Graha (2020). Immunoglobulin-A (IgA) Improvement through Sports and Frirage Massage. International Journal of Human Movement and Sports Sciences, 8(5), 271-282. DOI: 10.13189/saj.2020.080516.

Copyright $(\mathrm{C} 2020$ by authors, all rights reserved. Authors agree that this article remains permanently open access under the terms of the Creative Commons Attribution License 4.0 International License

\begin{abstract}
Background: All massages, including sports massages and frirage massage can reduce muscle tension, improve blood circulation, increase aggressiveness, increase nerve delivery, and reduce blood pressure and pulse rate. The aim of this study was to evaluate the effect of sports massage on changes in IgA levels. Method: This research is an experimental study with a pretest-posttest design. The research sample was 27 subjects divided into three groups: Technique collection data with blood drawing in vena of the three groups before and after treatment. Results showed that the sports massage treatment results in $\mathrm{P}>0.05$, which means that there is no positive effect of sports massage treatment on increasing IgA immunity. In the frirage massage treatment, $\mathrm{P}>0.05$ was obtained, which means that no positive effect on the increasing of immune IgA was found. Likewise in the control group the $\mathrm{P}$ value was not significant with a $\mathrm{P}$ value $>0.05$. This means that the one way ANOVA statistical test found that the two treatment groups, namely the sports massage and frirage massage groups did not have a significant effect on increasing IgA levels in the blood. When seen in the data on the mean results of the sports massage treatment group of $36.22 \mathrm{mg} / \mathrm{dl}$, the frirage massage treatment was $32.44 \mathrm{mg} / \mathrm{dl}$, but after being tested by one way ANOVA showed that the two groups were not significant. Conclusion: Sports massage to athletes performed heavy work and or exercise at high intensity may increase IgA.
\end{abstract}

Keywords Massage, High Intensity, Weight Training,
Antibody IgA

\section{Introduction}

Massage therapy is one of many forms of rehabilitation treatment that has long been used as an additional treatment for various mental and physical conditions [1]. In recent times, massage has gained more popularity in clinical wards because of its application to different ranges of patients from children and also in professional people in the competitive sports field and sedentary people from all walks of life. The best way to describe massage practices is as the mechanical manipulation of body tissues by applying rhythmic pressure [2]. One of the starting mechanisms of massage is through stimulation of different mechanoreceptors nervous system found on the skin (e.g. Meissner and Pacinian corpuscles, Merkel disc ends, Ruffini and free nerve ends) [3]. The pressure given to this receptor is then translated into different effects. More specifically, it can activate pathways that send signals along long nerve fibres and myelin to the limbic region of the brain or can affect release such as substance $\mathrm{P}$ or serotonin which is considered responsible for mediating 'relaxing effects [4]. This evidence shows that emotional well-being and neuronal modulation are key elements for the effectiveness of massage therapy. The catecholamine's released on lymphoid organs under central nervous system 
level control are known as regulators of the immune repertoire. To test the possibility that the mediation of the effects of massage therapy increases catecholamine. Immunofluorescence analysis of the thymus section for catecholamine nerve fibres shows a significant reduction in fluorescence intensity in both cortical and cortico-medulla junction areas in rat samples as treated with effleurage massage compared to controls [5].

Sports massage is very well known in Indonesia and almost all experts in massage therapy for national athletes have practiced them so that all athletes have benefited a lot from sports massage in which the manipulation techniques include effleurage, petrissage (squishing and pressing), shaking, friction, tapotemen (beating, hacking, clapping), walken (variation of effleurage), vibration, stroking, skin-rolling, and chiropractice.

Sports massage is a massage that is specifically used or given to healthy people, especially sportsmen. The target of sports massage is certain parts of the body of a healthy person. The types and methods of massage are preferred to improve the smooth circulation of blood [6] Sports massage is known as manual therapy, manipulative therapy, or manual manipulative therapy, this is a physical treatment mainly used on the neuromusculoskeletal system to treat pain and disability. The most common technique includes squeezing and muscle manipulation, joint mobilization, and joint manipulation. [7] argues that sports massage is a specific application of massage techniques, hydrotherapy protocols, various principles of flexibility motion and strength used to achieve certain goals when treating an athlete that is divided to before competing and after competing. Massage increases muscle fulfilment and reduces worse conditions in cross-coupling coupling, vertical jump, speed, and reaction time [8]. The purpose of application of sports massage in general is: (1) to improve blood circulation, especially the urge to venous blood to the heart. The continuity of blood circulation will then accelerate the process of removing the residues of incineration and the spread of food extracts to tissues; (2) to stimulate nerve, especially peripheral nerves to increase sensitivity to stimulation; (3) to increase muscle tension (tone) and muscle elasticity to enhance work power; (4) to cleanse and smoothen the skin; (5) to reduce or eliminate nervous tension and reduce pain, in order to be able to put the patient to sleep [9] Sports massage can cause multi-direct changes in the metabolism of selected biological compounds. Stimulation massage increases the functional state of neuromuscular devices and activates energy production which shows the formation of mechanisms needed for 'emergency' adaptation [10]. Effleurage massage therapy can reduce pain and disability of Myofacial Trigerpoin Syndrome in the upper trapezius muscle [11]. Mark Rapaport in his study states that the time needed for effective massage was 45 minutes [12]. Sports massage which is also known as the manual therapy and manipulative therapy is a physical treatment mainly used on the neuromusculoskeletal system to treat pain and disability where the types and methods of the massage are preferred at improving muscle relaxation, the blood circulation [13], recovery between training or high intensity competition sessions, reducing the possibility of tissue damage, decreasing heart rate, improving the blood circulation and pressure, reducing muscle tension, increasing joint motion, and reducing pain, as well as multidirectional changing in the metabolism of important biological compounds, improving the functional state of neuromuscular devices and activating energy production. Therefore the massage can help the athlete achieves the effectiveness and the rate of the recovery [14].

In the recent 7 years in Indonesia, there is a new fitness massage method named frirage massage from Faculty of Sports, Yogyakarta State University in which the manipulation techniques only friction and effleurage which are carried out simultaneously. Frirage massage is a hand movement for massaging given to healthy people, especially sportsmen, which employ only the 2 main manipulations namely effleurage and friction using only the thumb and it has the same purpose as sports massage. The two manipulations begin with a.) the supine position and starting from the left leg, namely the back of the foot and toes, front calf / lower leg, groin / upper thighs, followed by the right leg, the foot and fingers -finger, front calf / lower leg, groin / upper thigh, the upper arm area, the back of the hand, palm, forearm, upper arm, abdomen and chest, forehead and face area., b.) the prone position starts from the left leg, namely the soles of the feet, ankles, lower limbs, upper limbs, followed by the right leg namely the soles of the feet, ankles, lower limbs, upper limbs, then the buttocks, back, shoulders, neck and neck.

Frirage massage, which is a massage done only with the thumb, uses the combination of two manipulation techniques, namely friction and efflurage simultaneously so that it is named "frirage" [3] Frirage masssage is one of the applied science in the field of therapy and rehabilitation, both for the interests of sports medication, health education, and eastern medication (alternative medication) which can be useful to help cure before medical treatment or after medical treatment as a prevention and treatment for injuryb [15]. Frirage massage can only be done with right and left thumbs depending on your preference and it is performed by moving your thumb to go forward towards and ends to the index finger while the other fingers act as footing for support. This movement is very easy to do and you will not easily get tired. In its development, frirage massage has been divided into 4 fields based on: namely 1) frirage massage for infants, 2) frirage massage for joint injury and muscle shear, 3) frirage massage for organ dysfunction, and 4) frirage massage for fitness and or rehabilitation.

The two types of massage, namely sports massage and frirage massage, can improve muscle performance, reduce pain, and increase aggressiveness, this increasing must also have an effect on increasing immunity. The possibility of 
this immune system is what makes it fitter and more aggressive to feel healthy, the immune system is called immunity. There are five different types (classes) of immunoglobulins or antibodies in human blood: IgG, IgA, $\operatorname{IgM}, \operatorname{IgD}$ and $\operatorname{IgE}$ [14-15]. IgG is present in the largest amount, followed by IgM and $\operatorname{IgA}$. IgD is much lower, and $\mathrm{IgE}$ is present in only minutes. IgM and $\mathrm{IgG}$ mainly protect us from infection in our body tissues, organs and blood. Immunoglobulin $\mathrm{A}(\operatorname{Ig} \mathrm{A})$ is an antibody that plays an important role in mucosal immunity. IgA exists in two forms, four-chain monomers in the blood and eight-chain structures, or dimers, in exocrine glandular secretions from mucous membranes, including mucus, saliva, and tears (OpenStax College., 2013: 959) are also secreted from mucosal epithelium. and neutralizes microbes in the lumen of mucosal tissues, such as the respiratory and digestive tracts [15].

According to B cells in different anatomical sites switch to different isotypes, partly because of the cytokines produced at those sites. In particular, B cells in mucosal tissue switch to IgA, which is the class of antibodies most efficiently transported through the epithelium to mucosal secretions, in charge of defending against microbes that try to enter through the epithelium. Switching to IgA is stimulated by transforming growth factor- $\beta$ (TGF- $\beta$ ), which is produced by many cell types, including $\mathrm{T}$ helper cells, in the mucosa and other tissues. Cytokines also stimulate switching to IgA. Because these cytokines are produced by myeloid cells, they can stimulate the IgA response in the absence of $\mathrm{T}$ helper cells [15].

According to [16] one of the mechanisms by which massage initiates its effects is through stimulation of the nervous system different mechanoreceptors found in the skin (e.g. Meissner and Pacinian corpuscles, Merkel disc tip, Ruffini and free nerve endings). The pressure exerted on these receptors is then translated into different effects. More specifically, it can activate a pathway that sends signals along long nerve fibers and myelin to the limbic area of the brain [17] or can affect the release of substances such as $\mathrm{P}$ or serotonin which are thought to be responsible for mediating the 'chain effect. or relax [18]. Together this evidence suggests that emotional well-being and neuronal modulation are key elements for the effectiveness of massage therapy [19] argue that catecholamines released in lymphoid organs under the control of the central nervous system level are known regulators of the immune repertoire. To examine the possibility that the mediating effect of massage therapy increases catecholamines, [20] measured noradrenaline concentrations and fluorescence intensity and density of noradrenergic nerve fibers in both thymus and spleen. Immunofluorescence analysis of the thymus section for catecholamine nerve fibers showed a significant reduction in fluorescence intensity in both cortical and cortico-medullary junction regions in rat samples treated with effleurage massage compared to controls. This is in line with the opinion of [21. 22], the fact that large noradrenergic nerve plexuses predominate in the subcapsular cortex and corticomedullary junction, where thymocytes reside are more mature. Reinforced by the results of [19], previous studies conducted in humans showed that effleurage massage increases vagal activity through stimulation of pressure receptors which ultimately signals the limbic system or reduces the release of norepinephrine in the bloodstream causing overall regulation of sympathetic activity. Interestingly, research and other research groups have shown sympathetic nerves which innervate lymphoid tissue as one of the main pathways of the nervous and immune systems communicating to maintain body homeostasis [23, 24] Most importantly according to $[26,27]$ the evidence suggests that the homeostatic cross-talk is responsible for "information processing. "such as behavioral conditioning or changes in external environmental factors and their translation into specific immune responses.

Giving effleurage massage to mouse samples showed a tendency to increase the number of thymocytes in T cells in lymphoid organs, this will result in increased excitability triggering the production of excess IgA immune [19].

In Indonesia, there has been no research on increasing immunity in the form of IgA through sports massage and frirage massage in athletes, although almost all therapists who graduated from the Sports Faculty of Yogyakarta State University apply this kind of massage. Furthermore, based on observational reports and information from students and athletes who have been treated using both types of massage, there are very significant changes in feelings of being fit, healthy, fit, and energetic. Of course, all these reports are sketchy and unproven.

On the basis of the foregoing, the researcher wants to prove the truth in a laboratory that IgA type immunoglobulin can be increased through sports massage and frirage massage.

In this study, group sports massage and frirage massage have applied for 45 minutes after a one-hour break of high-intensity physical activity in the form of circuit weight training. After a phase of frirage massage, the participant rested for one hour and then completed the blood test taken in the cubital vein to determine the modulation effect of frirage massage on IgA antibody levels.

Immunoglobulin levels in normal IgA serum are 69 $382 \mathrm{mg} / \mathrm{dl}$, or $49-269 \mathrm{IU} / \mathrm{ml}$ [28] while in this study, the normal levels of IgA antibodies were determined at 40-350 $\mathrm{mg} / \mathrm{dl}$.

In sports massage and frirage massage there are similarities and also typical differences found at the time of implementing the phrase. The similarity of two massages is 1) in terms of its purpose, both are to promote blood circulation, relax muscles, remove metabolic remnants, stimulate nerve edges, and reduce nervous tension, 2) in terms of the technique, both have friction, effleurage, tapotement, and walken, 3) in terms of targets, 
both are aimed for the common people and sportsmen, 4) the direction of both massage is towards the heart, 5) in both message, manipulation begins with legs, and 6) massage time ranges 45-60 minutes.

Table 1. Asspect of Sports Massage and Frirage Massage

\begin{tabular}{|c|c|c|}
\hline Aspect & Sports Massage & Frirage Massage \\
\hline Specific Goal & $\begin{array}{c}\text { Stimulating } \\
\text { comfortable and fit } \\
\text { feelings }\end{array}$ & $\begin{array}{c}\text { Stimulating } \\
\text { comfortable and fit } \\
\text { feelings }\end{array}$ \\
\hline Main Technique & $\begin{array}{l}\text { The main technique } \\
\text { is effleurage }\end{array}$ & $\begin{array}{c}\text { The main techniques } \\
\text { are effleurage and } \\
\text { friction }\end{array}$ \\
\hline Tool & $\begin{array}{c}\text { The surface of } \\
\text { hands, fist, fingers }\end{array}$ & Thumbs \\
\hline $\begin{array}{l}\text { The number of } \\
\text { Manipulation }\end{array}$ & 9 manipulations & 2 manipulations \\
\hline $\begin{array}{l}\text { Direction of } \\
\text { Movement }\end{array}$ & $\begin{array}{l}\text { Starting from upper } \\
\text { limb to the lower }\end{array}$ & $\begin{array}{l}\text { Starting from foot sole } \\
\text { to upper parts of the } \\
\text { body }\end{array}$ \\
\hline Initial Position & Face downward & Supine position \\
\hline $\begin{array}{l}\text { Pressing } \\
\text { Rhythm }\end{array}$ & $\begin{array}{l}\text { Adjusted to the } \\
\text { muscle size }\end{array}$ & $\begin{array}{l}\text { Adjusted to the } \\
\text { muscle size }\end{array}$ \\
\hline
\end{tabular}

Table 1 showed the strong aspect between two different of massage: Sports massage and Frirage massage. Sport massage was based on effleurage technique while frirage $m$ based on effleurage and friction. On the hand of tool sport massage used surface hand, fist and fingers in case frirage massage used Thumbs only. Differences of the two massage are also seen in the movement direction while that sport massage starting from upper limb to the lower but frirage was vice-visa. The initial position was different, for sport massage face downward and supine position for the frirage massage. Finally, the number of manipulations was different: 9 manipulations for sport massage and 2 manipulations for the frirage massage. Nevertheless, were some similarities like: comfortable and fit feelings. A very striking difference can be seen from his movement techniques, sports massage has reliable manipulation, namely effleurage carried out using the entire surface of the palm. The pressure in the sport massage is so soft and smooth that effleurage throughout the body gives warm and comfortable feelings for the massaged person [29].

\section{Materials and Research Methods}

\subsection{Procedure}

This research is an experimental study with a pretest-posttest design [30] the procedure in this study 1 . The subjects were measured blood pressure, respiratory rate, total pulse per minute, 2 . The strenuous activity was done in the form of weight training with the circuit method, 3. After doing the load training the circuit is immediately measured again blood pressure, respiratory rate and pulse per minute, 4 . Immediately taking $17 \mathrm{~mL}$ of blood through the cubital vein., 5 Divided into 3 groups, namely group 1 who will be treated with sports massage, group 2 who will be treated with frirage massage, and group 3 who will not be treated as control, 6. Rest for 1 hour. 7. Giving massage treatment for 45 minutes to the two treatment groups, 8 . The second blood was drawn with a cubital vein of $17 \mathrm{~mL}$ to all treatment and control groups, 9. The results of the blood collection were taken to Prodia's laboratory on Jl. Bintaran Kulon No 28 Yogyakarta to analyze IgA levels in the blood.

Weight training procedure with the following circuit: physical activity training that is a circuit weight training of 12 sessions and repetition 10 times / set as many as 3 sets at high intensity for 60 minutes, the training load of each muscle is $30 \%$ from $1 \mathrm{RM}$, each session lasted for 30 seconds, breaking intervals between training sessions was 60 seconds session, exercises were performed for 3 sets, and breaks between sets were 3-5 minutes. This is used as a basis for substituting tiring workout before being treated with massage.

Table 2. Implementation Guidelines for Sports Massage and Frirage massage

\begin{tabular}{|c|c|c|c|}
\hline 1. & Programme & Sports Massage & Frirage Massage \\
\hline 2. & Frequency & $\begin{array}{c}2 \text { blood tests in every } \\
\text { treatment }\end{array}$ & $\begin{array}{c}2 \text { blood tests in } \\
\text { every treatment }\end{array}$ \\
\hline 3. & Intensity & $\begin{array}{c}\text { The pressure } \\
\text { intensity depending } \\
\text { on the muscle size }\end{array}$ & $\begin{array}{c}\text { The pressure } \\
\text { intensity } \\
\text { depending on the } \\
\text { muscle size }\end{array}$ \\
\hline 4. & Time & $\begin{array}{c}45 \text { minutes, divided } \\
\text { into } 9 \text { kinds of } \\
\text { manipulation }=2700 \\
\text { seconds: } 48 \text { total } \\
\text { manipulation }=32 \\
\text { seconds: } 3,375 \\
\text { seconds/repetition } \\
7-8 \text { repetition / } \\
\text { manipulation }\end{array}$ & $\begin{array}{c}\text { 45 minutes, } \\
\text { divided into 2 } \\
\text { kinds of } \\
\text { manipulation with } \\
\text { 25 repetitions }\end{array}$ \\
\hline 5. & Type & $\begin{array}{c}\text { Figures and massage } \\
\text { order attached }\end{array}$ & $\begin{array}{c}\text { Figures and } \\
\text { massage order } \\
\text { attached }\end{array}$ \\
\hline
\end{tabular}

Table 2 showed the volume of each type of massage. Both of two massage sport massage and frirage massage were based on frequency, intensity, time, and type. Firstly, they had 2 blood tests in every treatment in the hand of frequency. For both of the two massage the pressure was based on the side of muscle. It has been seen a strong different on the hand of manipulation time while that sport massage has 48 manipulations in 2700 seconds for the first time and 32 manipulations in 3375 seconds for the second time. For the frirage massage only 2 types of manipulations with the same time with 25 repetitions.

Meanwhile, masseurs are professional therapists from the Therapy Clinic of the Sports Faculty of Yogyakarta State University.

The procedure for implementing the treatment in the two experimental groups was as follows: 


\begin{tabular}{|c|c|c|}
\hline \multicolumn{3}{|c|}{ Procedure Sports Massage } \\
\hline \multicolumn{3}{|c|}{ A. Face down (26 minutes) } \\
\hline Area of Contact & Kinds of Manipulation & Duration \\
\hline 1. Upper Limbs & Effleurage 1, 2, 3; Petrissage 1, 2; Effleurage 1.2.3. (Closing) & \multirow{3}{*}{$\begin{array}{l}\text { Time } \\
11 \text { minutes }\end{array}$} \\
\hline 2. Lower Limbs & Eflleurage 1.2; Petrissage; Shaking, Effleurage 1,2. (Closing) & \\
\hline 3. Feet and soles & Effleurage 1,2; Petrissage, Effleurage 1,2. (Closing) & \\
\hline 4. Waist and back & $\begin{array}{c}\text { Effleurage 1,2; Friction, Walken, Seterika, Tapotement (Beating, } \\
\text { Clapping, Hacking), Effleurage 1,2. (Closing) }\end{array}$ & \multirow{3}{*}{$\begin{array}{l}\text { Time } \\
15 \text { minutes }\end{array}$} \\
\hline 5. Butt & Effleurage, Friction, Walken, Tapotement, effleurage (Closing) & \\
\hline \multirow[t]{2}{*}{ 6. $\quad$ Nape and Shoulders } & Effleurage 1,2; Petrissage, Shaking, Effleurage 1,2 (Closing) & \\
\hline & Total Time A & 26 minutes \\
\hline \multicolumn{3}{|c|}{ A. Supine Position (19 Minutes) } \\
\hline 1. Upper Limbs & Effleurage 1, 2, 3; Petrissage 1, 2; Effleurage 1.2.3. (Closing) & \multirow{3}{*}{$\begin{array}{l}\text { Time } \\
10 \text { minutes }\end{array}$} \\
\hline 2. Lower Limbs & Eflleurage 1.2; Petrissage; Shaking; Effleurage 1,2. (Closing) & \\
\hline 3. Instep and Foot & Effleurage 1,2; Petrissage; Shaking; Effleurage 1,2. (Closing) & \\
\hline 4. Lower and Upper Arms & Effleurage 1,2; Petrissage; Shaking 1,2; Effleurqage 1,2. (Closing) & \multirow{3}{*}{$\begin{array}{l}\text { Time } \\
8 \text { minutes }\end{array}$} \\
\hline 5. Backs of Hands and Palms & Effleurage; Shaking; Effleurage (Closing) & \\
\hline 6. Chest and Stomach & Effleurage; Walken; Shaking; Effleurage (Closing) & \\
\hline \multirow[t]{3}{*}{ 7. Forehead and Nose } & Effleurage Forehead; Effleurage on the nose and down the temples & $\begin{array}{l}\text { Time } \\
1 \text { minutes }\end{array}$ \\
\hline & Total Time B & 19 minutes \\
\hline & Total Sum of Time A + B & 45 minutes \\
\hline
\end{tabular}

\begin{tabular}{|c|c|c|}
\hline \multicolumn{3}{|c|}{ Procedure Frirage Massage } \\
\hline \multicolumn{3}{|c|}{ Supine Position (20 Minutes) } \\
\hline Area of Contact & Kinds of Manipulation & Duration \\
\hline Backs, Fingers Legs and Feet. & With your thumb, work on areas $1,2,3$ and 4 . & \multirow{3}{*}{$\begin{array}{l}\text { Time } \\
10 \text { minutes }\end{array}$} \\
\hline Front calves and knees. & With your thumb, work on areas 1, 2, 3 and 4. & \\
\hline Front thigh and groin. & With your thumb, work on areas $1,2,3$ and 4 . & \\
\hline Backs Right hand and Left & With your thumb, work on areas $1,2,3$ and 4 . & \multirow{6}{*}{$\begin{array}{l}\text { Time } \\
10 \text { minutes }\end{array}$} \\
\hline Palm of the hand & With your thumb, work on areas $1,2,3$ and 4 . & \\
\hline $\begin{array}{c}\text { Forearm } \\
\begin{array}{c}\text { Massage starts on the outer arm from the wrist } \\
\text { to the elbow area. }\end{array} \\
\end{array}$ & $\begin{array}{l}\text { Do this with the thumbs on the outer forearms in areas } 1,2 \text {, and } 3 \\
\text { followed by on the inner forearms in areas } 4,5 \text { and } 6 \text {. }\end{array}$ & \\
\hline $\begin{array}{c}\text { Upper arm } \\
\text { Massage starts from the elbow area to the } \\
\text { shoulder area, the position of the arm bent over } \\
\text { the chest. }\end{array}$ & $\begin{array}{l}\text { Do this with the thumb on the outer upper arm in areas } 1,2 \text { and } 3 \text {, } \\
\text { followed by the inner upper arm in areas } 4,5 \text { and } 6 .\end{array}$ & \\
\hline $\begin{array}{l}\text { Stomach } \\
\text { Massage starts from the right abdomen from } \\
\text { the bladder border rib area. }\end{array}$ & $\begin{array}{l}\text { Do it with the left thumb followed by the lower middle stomach } \\
\text { starting } 2 \text { fingers from the navel to the point of the stomach }\end{array}$ & \\
\hline \multirow[t]{2}{*}{$\begin{array}{l}\text { Chest } \\
\text { The massage starts from the right side by } \\
\text { applying the ribs to the clavicle area. }\end{array}$} & $\begin{array}{l}\text { Do it with the thumb from the edge along the chest from the } \\
\text { bottom outwards continued upwards around the inside of the } \\
\text { chest. }\end{array}$ & \\
\hline & Total Time A & 20 Minutes \\
\hline
\end{tabular}




\begin{tabular}{|c|c|c|}
\hline \multicolumn{3}{|c|}{ Prone Position (25 Minutes) } \\
\hline Area of Contact & Kinds of Manipulation & Duration \\
\hline $\begin{array}{l}\text { Left foot. } \\
\text { Massage starts from the left leg in the way } \\
\text { shown in the picture. }\end{array}$ & $\begin{array}{c}\text { a) Only with the thumb } \\
\text { Perform friction and efflleurage (frirage) straight ahead towards } \\
\text { the heart with the thumb striking the edge (1) middle (2) and the } \\
\text { concave part. }\end{array}$ & \multirow{4}{*}{$\begin{array}{l}\text { Time } \\
10 \text { minutes }\end{array}$} \\
\hline $\begin{array}{l}\text { Left ankle } \\
\text { The grip for the ankle area is adjusted } \\
\text { according to the direction or target of the } \\
\text { manipulation. }\end{array}$ & $\begin{array}{l}\text { With the thumb, the lateral (outer) part of the ankle, do it with the } \\
\text { right hand, on lines } 1,2 \text { and } 3 .\end{array}$ & \\
\hline 3) Lower limbs & $\begin{array}{l}\text { With your thumb, start from the calcani to the back of the knee } \\
\text { crease }\end{array}$ & \\
\hline 4) Upper limbs & $\begin{array}{l}\text { With your thumbs, starting from the top of the knee to the crease } \\
\text { of the thigh, apply the movement to the upper, inner and outer } \\
\text { sides of the thigh. }\end{array}$ & \\
\hline 5) Butt & $\begin{array}{l}\text { With the thumb, start from the bottom of the buttocks towards the } \\
\text { upper buttocks, hitting the top, outer side and a little inside }\end{array}$ & \multirow{4}{*}{$\begin{array}{c}\text { Time } \\
15 \text { minutes }\end{array}$} \\
\hline 6) Back & $\begin{array}{l}\text { With the thumb starting from the top of the buttocks to the nape } \\
\text { of the neck along the side of the vertebrae, starting from the } \\
\text { bottom again around the back muscles to the nape of either the } \\
\text { right side of the vertebrae or on the left }\end{array}$ & \\
\hline 7) Shoulders & With your thumbs starting from the shoulder muscles to the nape & \\
\hline \multirow[t]{3}{*}{ 8) Nape and Neck } & $\begin{array}{l}\text { With the thumb, start from the muscle beside the cervical spine up } \\
\text { to the back of the ear }\end{array}$ & \\
\hline & Total Time B & 25 Minutes \\
\hline & Total Time A + B & 45 minutes \\
\hline
\end{tabular}

\subsection{Participants}

This experimental research was conducted using the pretest-posttest design. The number of samples as research subjects was obtained in accordance with the inclusion criteria of 1) male, 2) the age range of 19-21 years, 3) were not athletes of district, regional, national and international, 3) willing and able to carry out tasks in this study, 4) willing to be the sample, and 5) the status of 4th semester students of the Study Program of Sports Science and Health of Faculty of Sports, Yogyakarta State University class 2016. The research subjects are 32 males and during the research there were 5 subjects who could not continue the study, so that the overall subjects were 27 male students of the study programme of IKOR Yogyakarta State University, Indonesia. Prior to the research, the subjects signed consent letters, the willingness to be the subject of research. During the research the subjects divided into 3 groups, namely the groups of sports massage (X1), frirage massage (X2) and control (X3) treated with the placebo massage or control.

\subsection{Data Collection}

In this study, the taking of IgA serum in the form of blood was through the cubital vein performed twice. The first was before carrying out heavy workout of weight training circuit with a $7 \mathrm{~mL}$ and the second was one hour after massage. The IgA antibody was determined by the ELISA (Enzyme-Linked Immunosorbent Assay) method carried out by indirect sandwich using Siemen Healthcare
Diagnostics Inc., SIEMENS. Data were interpreted using Elisa Reader with 95\% sensitivity. The level of immunoglobulin in normal serum IgA is $40-350 \mathrm{mg} / \mathrm{dl}$ [31].

\section{Statistical Analysis}

Normality (Shapiro-Wilks), homogeneity (Levene Test), and T-test of data were undertaken by using SPSS V.19.0 suit off program.

\subsection{Research Formulations}

On the basis of background of the study above, the problem is formulated as follows:

1. Does sports massage have effects on changes in IgA antibody levels?

2. Does frirage massage have effects on changes in $\operatorname{IgA}$ antibody levels?

3. Which of sports and frirage massage is most effective on changes in IgA antibody levels?

\section{Results}

Table 3 showed the characteristics of three groups which are sports massage, frirage massage, and group control. In this table the result of pre-test and posttest of IgA IMUN has been presented. Therefore, it was found a difference between their means and standard deviation (SD). 


\subsection{Data Analysis}

The normality test of immunoglobulin A (IgA) levels data indicates that data is normally distributed with $p>\alpha$ 0.05 .

Table 4 showed that in statistics, normality tests are used to determine if a data set is well-modeled by a normal distribution and to compute how likely it is for a random variable underlying the data set to be normally distributed. In this table the result showed that $\mathrm{P}$ value was $>0.05$ and it can conclude that data were normal distributed.

Table 5 showed that homogeneity test of immunoglobulin A (IgA) levels data were analyzed by using the Levene's technique. It is obtained that $\mathrm{F}>\alpha 0.05$, meaning the working hypothesis is rejected and the null hypothesis is accepted. Thus it can be concluded that the final data of the population variants in the treatment group is homogeny.

Table 3. Descriptive Data Group Experiment and Control

\begin{tabular}{|c|c|c|c|c|c|c|}
\hline \multirow{3}{*}{ KET } & \multirow{2}{*}{\multicolumn{2}{|c|}{$\frac{\text { SPORTS MASSAGE }}{\text { IgA IMUN }}$}} & \multirow{2}{*}{\multicolumn{2}{|c|}{$\begin{array}{c}\text { FRIRAGE MASSAGE } \\
\text { IgA IMUN }\end{array}$}} & \multirow{2}{*}{\multicolumn{2}{|c|}{$\begin{array}{c}\text { CONTROL } \\
\text { IgA IMUN }\end{array}$}} \\
\hline & & & & & & \\
\hline & POST & PRE & POST & PRE & POST & PRE \\
\hline & 337 & 302 & 258 & 232 & 192 & 194 \\
\hline & 307 & 258 & 275 & 221 & 388 & 361 \\
\hline & 320 & 284 & 229 & 205 & 197 & 187 \\
\hline & 237 & 208 & 242 & 203 & 307 & 298 \\
\hline & 250 & 205 & 226 & 193 & 220 & 211 \\
\hline & 242 & 214 & 166 & 147 & 178 & 174 \\
\hline & 220 & 183 & 316 & 272 & 229 & 228 \\
\hline & 304 & 259 & 207 & 182 & 209 & 213 \\
\hline & 276 & 254 & 217 & 189 & 316 & 325 \\
\hline Sum & 2493 & 2167 & 2136 & 1844 & 2236 & 2191 \\
\hline Mean & 277.0000 & 240.7778 & 237.3333 & 204.8889 & 248.4444 & 243.4444 \\
\hline Median & 276.0000 & 254.0000 & 229.0000 & 203.0000 & 220.0000 & 213.0000 \\
\hline Variance & 1735.250 & 1603.694 & 1834.500 & 1221.361 & 5125.778 & 4514.778 \\
\hline Std. Deviation & 41.65633 & 40.04615 & 42.83106 & 34.94798 & 71.59454 & 67.19210 \\
\hline Minimum & 220.00 & 183.00 & 166.00 & 147.00 & 178.00 & 174.00 \\
\hline Maximum & 337.00 & 302.00 & 316.00 & 272.00 & 388.00 & 361.00 \\
\hline Range & 117.00 & 119.00 & 150.00 & 125.00 & 210.00 & 187.00 \\
\hline
\end{tabular}

Table 4. Tests of Normality

\begin{tabular}{|c|c|c|c|c|c|c|}
\hline \multirow{2}{*}{ EXPERIMENT } & \multicolumn{3}{|c|}{ Kolmogorov-Smirnov $^{a}$} & \multicolumn{3}{|c|}{ Shapiro-Wilk } \\
\hline & Statistic & df & Sig. & Statistic & df & Sig. \\
\hline SPORTS-MASSAGE & .170 & 9 & $.200^{*}$ & .956 & 9 & .757 \\
\hline SPORTS-MASSAGE & .209 & 9 & $.200^{*}$ & .923 & 9 & .414 \\
\hline SPORTS-MASSAGE & .206 & 9 & $.200^{*}$ & .930 & 9 & .481 \\
\hline
\end{tabular}

Table 5. Test of Homogeneity of Variances

\begin{tabular}{|c|c|c|c|c|c|}
\hline & Levene Statistic & df1 & df2 & Sig. & Sig \\
\hline PRE-TEST IgA & 4.039 & 2 & 24 & .031 & Sig F $>\alpha 0.05$ \\
\hline POST-TEST IgA & 2.670 & 2 & 24 & .090 & Sig F $>\alpha 0.05$ \\
\hline
\end{tabular}

Table 6. One Way Anova

\begin{tabular}{|c|c|c|c|c|c|c|}
\hline \multicolumn{7}{|c|}{ ANOVA } \\
\hline & & Sum of Squares & $\mathrm{df}$ & Mean Square & $\mathrm{F}$ & Sig. \\
\hline \multirow{3}{*}{ SPORTS MASSAGE } & Between Groups & 5904.222 & 1 & 5904.222 & 3.537 & .078 \\
\hline & Within Groups & 26711.556 & 16 & 1669.472 & & \\
\hline & Total & 32615.778 & 17 & & & \\
\hline \multirow{3}{*}{ FRIRAGE MASSAGE } & Between Groups & 4736.889 & 1 & 4736.889 & 3.100 & .097 \\
\hline & Within Groups & 24446.889 & 16 & 1527.931 & & \\
\hline & Total & 29183.778 & 17 & & & \\
\hline \multirow{3}{*}{ CONTROL } & Between Groups & 112.500 & 1 & 112.500 & .023 & .880 \\
\hline & Within Groups & 77124.444 & 16 & 4820.278 & & \\
\hline & Total & 77236.944 & 17 & & & \\
\hline
\end{tabular}


Table 6 showed that the sports massage treatment results in $\mathrm{P}>0.05$, which means that there is no positive effect of sports massage treatment on increasing IgA immunity. In the frirage massage treatment, $\mathrm{P}>0.05$ was obtained, which means that the frirage massage treatment did not have a positive effect on the increase in immune IgA. Likewise in the control group the $\mathrm{P}$ value was not significant with a $\mathrm{P}$ value $>0.05$. This means that the one way ANOVA statistical test found that the two treatment groups, namely the sports massage and frirage massage groups did not have a significant effect on increasing IgA levels in the blood. When seen in the data on the mean results of the sports massage treatment group of $36.22 \mathrm{mg} /$ $\mathrm{dl}$, the frirage massage treatment was $32.44 \mathrm{mg} / \mathrm{dl}$, but after being tested by one way ANOVA showed that the two groups were not significant.

Although the results show that the two treatment groups are declared insignificant, it can be seen whether the increase in IgA levels in the two groups is more effective as followed table 7 .

The results of the discussion in Table 7. The Least Significance Difference (LSD) Technique the Mean Difference between Treatment Groups of Each Dependent Variable explains the differences in the increase in IgA immune levels:

Because the results of the calculation of the significance of sports massage with frirage massage is less than $\alpha 0.05$ $(0,000<0.05)$, there is a significant difference between sports massage with frirage massage on increasing levels of IgA immune. Because the sports massage with the frirage massage results of the Confidence Interval For Difference results does not contain zero (0) and has a positive $(+)$ value, the sports massage is greater for an increase in IgA immune levels compared to the frirage massage.

The results show that: Sports massage is more effective in increasing IgA antibody levels than frirage massage $(0,000<0.05)$.

\section{Discussions}

The best way to describe the practice of massage to mechanically manipulate body tissue is by applying rhythmic pressure. Furthermore, one of the mechanisms giving to massage impacts is by stimulating mechanoreceptors nervous system found in the skin (eg. Meissner and Pacinian corpuscles, Merkel disc tip, Ruffini and free nerve endings). The pressure applied to the receptors activates pathways that send signals along nerve fibres and myelin to limbic regions of the brain $[32,33]$ or affects the release of such substances $\mathrm{P}$ or serotonin considered responsible for mediating 'relax', These suggest that emotion and neuronal modulation are key elements for the effectiveness of massage therapy. Catecholamine released in lymphoid organs under central nervous system control is known as regulators of the immune repertoire [34].

Table 7. Multiple Comparisons

\begin{tabular}{|c|c|c|c|c|c|c|c|}
\hline \multicolumn{8}{|l|}{ LSD } \\
\hline \multirow{2}{*}{ Dependent Variable } & \multirow{2}{*}{ (I) EXPERIMENT } & \multirow{2}{*}{ (J) EXPERIMENT } & \multirow{2}{*}{$\begin{array}{c}\text { Mean } \\
\text { Difference } \\
(\mathrm{I}-\mathrm{J})\end{array}$} & \multirow{2}{*}{ Std. Error } & \multirow{2}{*}{ Sig. } & \multicolumn{2}{|c|}{$\begin{array}{c}95 \% \text { Confidence } \\
\text { Interval } \\
\end{array}$} \\
\hline & & & & & & $\begin{array}{l}\text { Lower } \\
\text { Bound }\end{array}$ & $\begin{array}{l}\text { Upper } \\
\text { Bound }\end{array}$ \\
\hline \multirow{6}{*}{ POST-TEST IgA } & \multirow{2}{*}{ SPORTS-MASSAGE } & FRIRAGE MASSAGE & 39.66667 & 25.37938 & .131 & -12.7138 & 92.0471 \\
\hline & & CONTROL GROUP & 28.55556 & 25.37938 & .272 & -23.8249 & 80.9360 \\
\hline & \multirow{2}{*}{ FRIRAGE MASSAGE } & SPORTS-MASSAGE & -39.66667 & 25.37938 & .131 & -92.0471 & 12.7138 \\
\hline & & CONTROL GROUP & -11.11111 & 25.37938 & .665 & -63.4916 & 41.2694 \\
\hline & \multirow{2}{*}{ CONTROL GROUP } & SPORTS-MASSAGE & -28.55556 & 25.37938 & .272 & -80.9360 & 23.8249 \\
\hline & & FRIRAGE MASSAGE & 11.11111 & 25.37938 & .665 & -41.2694 & 63.4916 \\
\hline
\end{tabular}

*. The mean difference is significant at the 0.05 level. 
IgA levels in the blood increase with moderate exercise, sports massage and the frirage massage applied with weight circuit training for 1 hour and rest of 1 hour cannot increase immune. This can all occur because it is suspected that weight training is considered too heavy so that it results in psychological and physiological pressure, this is reinforced by the results of research from [35] who conducted a study to determine the response of s- IgA on top 10 Brazilian professional futsal players after 2 very competitive matches separated by 7 days. Unstimulated saliva was collected for 5 minutes before and after the match. S-IgA is measured. The results showed that competitive match training triggered a decrease in the s-IgA levels of top-level futsal players, which suggests an increase in susceptibility to infection was mediated by the training stimulus. This decrease indicates that athletes are at increased risk of developing upper respiratory tract infections. This conclusion is reinforced by Rosa Adriana Jarillo-Luna, et al [36] that intense psychological and physical stress can increase susceptibility to infection by various pathogens in the upper respiratory tract. [37] studied Decreased salivary immunoglobulins after intense interval exercise before and after training, the results showed that IgA and IgM concentrations relative to total protein decreased after each exercise session; $\operatorname{IgG}$ concentrations relative to total protein did not change after exercise. $\operatorname{Ig} \mathrm{A}$, IgM, and $\operatorname{IgG}$ flow rates decrease $50-65 \%$ after interval training. No training effect on the immune parameters was measured, although the total work done in the five attacks 60 seconds increased after training. These data suggest that salivary IgA and IgM output decreases after brief supramaximal interval training, and that the reduction in output is due, at least in part, to decreased salivary flow. In addition, there appears to be a specific effect of intense exercise at greater IgA concentrations than those caused by decreased salivary flow alone.

In addition to cell proliferation, the recovery phase from exercise, especially after very long endurance-based exercise, is characterized by a marked change in the functional capacity of some blood leukocyte populations. Neutrophilic bactericidal activity is strongly influenced by the intensity and duration of exercise. For example, 1 hour cycling at 50 vs. $80 \%$ Vंo2max increased respectively and reduced the oxidative blast activity of neutrophils [38]. During the early stages of recovery after exercise, neutrophilic bactericidal activity continues to increase after 40 minutes to 1 hour of moderate intensity exercise, whereas it remains disrupted after tiring or prolonged exercise (86). NK cell cytotoxicity after exercise attacks of relatively short duration tends to remain unchanged on a per cell basis during recovery [39] but may decrease after very long attacks [40]. T cell proliferation in response to mitogen stimulation usually decreases during and after exercise, regardless of exercise modality, intensity, or duration [ Prolonged exercise can also reduce T-cell movement and displacement

[41], lipopolysaccharide-induced cytokine secretion by monocytes [42] and the percentage of $\mathrm{T}$ cells that produce effector cytokines in response to mitogen stimulation [43]. Thus, a general trend during exercise recovery is that brief, moderate-intensity exercise has little effect on (or perhaps even enhances) cellular immune function, whereas prolonged bouts ( $>1.5$ hours) of strenuous activity appear to reduce the normal functioning of all major activities. immune cell subtypes. This effect can make athletes susceptible to disease during recovery from vigorous competition or training [44].

Studies over a short period (2-4 weeks) of excess function have reported decreased resting neutrophil degranulation [45] lymphocyte proliferation, and antibody production [45]. Neutrophil counts, plasma cytokine concentrations, CD4-to-CD8 T-cell ratio, and salivary IgA concentrations varied more (or did not change) in response to borderline function $[46,47,48,49]$. Athletes who show signs of nonfunctional overreach and / or frequent upper respiratory disease with lower salivary IgA concentrations $[50,51,52]$; decreases cytokine production by monocytes, neutrophils, and dendritic cells [53] and more activated lymphocytes $(\mathrm{CD} 25+)$ [54]. Changes in differential blood cell counts, lymphocyte subsets, and NK cell counts after an extended period of intense training varied $[55,56,57]$. Studies of athletes demonstrating the features of overtraining syndrome (including disease) have not revealed a consistent or characteristic immune profile [58, 59].

On the basis of the foregoing, the treatment of sports massage and frirage massage has not been able to increase IgA levels in the blood because it is suspected that including a rest time of only 1 hour.Then the massage for 45 minutes results in inhibiting $T$ cell movement, secretion of cytokines induced by lipopolysaccharides by monocytes and cell percentage. T which produces effector cytokines in response to mitogen stimulation which results in little effect on cellular immune function, on the other hand, circuit weight training only once including massage treatment in each group also only once.

\section{Conclusions}

1. Massage eexercises cannot significantly increase IgA antibody levels after strenuous exercise.

2. Frirage massage cannot significantly increase $\operatorname{IgA}$ antibody levels after strenuous exercise.

3. Sports massage was more effective in increasing IgA antibody levels after strenuous exercise than frirage massage and the control.

It is recommended to expand and increase the number of samples in order to draw more precise conclusions from the research results. Blood draws should be done before getting any activity. Data collection in the form of blood tests to measure IgA antibody levels was only done twice. 
Firstly before strenuous exercise and secondly after resting for 1 hour after massage, which should be measured four times before doing strenuous activity, after resting for 1 hour of strenuous activity, after massage, and 1-2 hours after massage in order to get precise results in research. Data collection should not only be done in one day, but preferably for 2 weeks and training and measurements should be carried out three times a week to obtain more objective and accurate results.

\section{Acknowledgements}

I am grateful to all the sport science students of Yogyakarta State University who have been pleased to be the samples, and the masseurs who generously assisted the treatments.

\section{REFERENCES}

[1] B. Major, L. Rattazzi, S. Brod, I. Pilipović, G. Leposavić, and F. D'Acquisto, "Massage-like stroking boosts the immune system in mice," Sci. Rep., vol. 5, no. June, 2015.

[2] V. Tejero-Fernández, M. Membrilla-Mesa, N. Galiano-Castillo, and M. Arroyo-Morales, "Immunological effects of massage after exercise: A systematic review," Phys. Ther. Sport, vol. 16, no. 2, pp. 187-192, 2015.

[3] T. Field, M. Diego, and M. Hernandez-Reif, "Moderate pressure is essential for massage therapy effects," Int. J. Neurosci., vol. 120, no. 5, pp. 381-385, 2010.

[4] D. Sliz, A. Smith, C. Wiebking, G. Northoff, and S. Hayley, "Neural correlates of a single-session massage treatment," Brain Imaging Behav., vol. 6, no. 1, pp. 77-87, 2012.

[5] C. W. Banker, "Immunomodulatory Effects of Massage in Skeletal Muscle," 2013.

[6] A. S. Graha and B. Priyonoadi, "Terapi masase frirage penatalaksanaan cedera pada anggota gerak tubuh bagian bawah," Fak. Ilmu Keolahragaan Univ. Negeri Yogyakarta, pp. 1-109, 2012.

[7] McGillicuddy M (2003) McGillicuddy M, Three Key Principles of Sports Massage: Massage Today. May, 2003, Vol. 03, Issue 05.http://www.massagetoday.com/digital/ind ex.php?i=637\#1. Diunduh Rabu, 8/06/2016. Pkl 13.43.

[8] R. Arabaci, "Acute effects of pre-event lower limb massage on explosive and high speed motor capacities and flexibility," J. Sport. Sci. Med., vol. 7, no. 4, pp. 549-555, 2008.

[9] Graha \& Priyonoadi, 2012; G. Satria, ALi dan Priyonoadi, “Terapi Massage Frirage," pp. 1-95, 2012.

[10] B. Priyonoadi, A. Satia Graha, R. Laksmi Ambardini, and B. M. W. Kushartanti, "The Effectiveness of Post-Workout Fitness and Sports Massage in Changing Blood Pressure, Pulse Rate, and Breathing Frequency," vol. 278, no. YISHPESS, pp. 529-533, 2019
[11] M. H. Rapaport, P. Schettler, and C. Bresee, "A preliminary study of the effects of a single session of Swedish Massage on hypothalamic-pituitary-adrenal and immune function in normal individuals," J. Altern. Complement. Med., vol. 16, no. 10 , pp. $1079-1088,2010$

[12] S. Harsanti and A. S. Graha, "Efektifitas Terapi Masase dan Terapi Latihan Pembebanan Dalam Meningkatkan Range of Movement Pasca Cedera Ankle Ringan," J. Med. Vol. XIII No. 1 Oktober 2014 Ef., vol. XIII, no. 1, 2014.

[13] Satria, Ali dan B. Priyonoadi, “Terapi Massage Frirage,” pp. 1-95, 2012.

[14] OpenStax College. (2013). Anatomy and Physiology. Rice University, 6100 Main Street MS-380 Houston, Texas 77005. ISBN-13978-1-938168-13-0, Revision AP-1-001-DW.

[15] Abbas A K., Lichtman A H., Pillai S., (2015). Cellular and molecular immunology. Eighth edition, by Saunders, an imprint of Elsevier Inc. 1600 John F. Kennedy Blvd. Ste 1800 Philadelphia, PA 19103-2899. ISBN 978-0-323-22275-4.

[16] Field T., Diego M. \& Hernandez-Reif M. Moderate pressure is essential for massage therapy effects. Int J Neurosci 120, 381-385, (2010).10.3109/ 002074509035 79475. [PubMed] [Cross Ref]

[17] Sliz D., Smith A., Wiebking C., Northoff G. \& Hayley S. Neural correlates of a single-session massage treatment. Brain Imaging Behav 6, 77-87, (2012).10.1007/s 11682-011-9146-z [PMC free article] [PubMed] [Cross Ref]

[18] Listing M. et al. The efficacy of classical massage on stress perception and cortisol following primary treatment of breast cancer. Arch Womens Ment Health 13, 165-173, (2010).10.1007/s00737-009-0143-9 [PubMed] [Cross Ref]

[19] Major Benjamin, Rattazzi Lorenza, Brod Samuel, Pilipović Ivan, Leposavić Gordana, and D'Acquisto Fulvio (2015). Massage-like stroking boosts the immune system in mice. Sci Rep. 2015; 5: 10913. Published online 2015 Jun 5. doi: 10.1038/ srep10913 PMCID: PMC4650642

[20] Banker, Christine Waters, (2013). "Immunomodulatory Effects of Massage in Skeletal Muscle". Dissertations-Rehabilitation Sciences. University of Kentucky Uknowledge, Paper 18. chris.waters24@gmail.co m.http:// uknowledge. uky. edu/rehabsci_etds/18.

[21] Herman PM, Poindexter BL, Witt CM, Eisenberg DM. Are complementary therapies and integrative care cost-effective? A systematic review of economic evaluations. BMJ Open. $2012 ; 2(5)$

[22] Hawk C, Ndetan H, Evans MW, Jr. Potential role of complementary and alternative health care providers in chronic disease prevention and health promotion: an analysis of National Health Interview Survey data. Prev Med. Jan 2012;54(1):18-22.

[23] Diego M. A. \& Field T. Moderate pressure massage elicits a parasympathetic nervous system response. Int J Neurosci 119,630-638,(2009).10.1080/002074508023 29605 [PubMed] [Cross Ref]

[24] I. Pilipović et al., "Catecholaminergic signalling through thymic nerve fibres, thymocytes and stromal cells is 
dependent on both circulating and locally synthesized glucocorticoids," Exp. Physiol., vol. 97, no. 11, pp. 12111223, 2012.

[25] Leposavic G., Pilipovic I. \& Perisic M. Age-associated remodeling of neural and nonneural thymic catecholaminergic network affects thymopoietic productivity. Neuroimmunomodulation 18, 290-308, (2011).10.1159/000329499 [PubMed] [Cross Ref].

[26] Costa-Pinto F.A. \& Palermo-Neto J. Neuro immune interactions in stress. Neuro immune modulation17,196-199, (2010).10.1159/000258722 [PubMed] [Cross Ref]

[27] Dhabhar F. S., Malarkey W. B., Neri E. \& McEwen B. S. Stress-induced redistribution of immune cells-from barracks to boulevards to battlefields: a tale of three hormones-Curt Richter Award winner. Psychoneuroendocrinology 37, 1345-1368, (2012).10.1016/j.psyneuen.2012.05.008 [PMCfreearticle] [PubMed] [Cross Ref]

[28] Siswantoyo, (2007). Pengaruh Olahraga Pernafasan "Satria Nusantara Tingkat Pradasar-Dasar" Terhadap Modulasi Imunitas. (Disertasi Doktor tidak dipublikasikan). Universitas Airlangga.

[29] B. Priyonoadi, A. Satia Graha, R. Laksmi Ambardini, and B. M. W. Kushartanti, "The Effectiveness of Post-Workout Fitness and Sports Massage in Changing Blood Pressure, Pulse Rate, and Breathing Frequency," vol. 278, no. YISHPESS, pp. 529-533, 2019.

[30] Sugiyono, (2013). Statistika Untuk Penelitian. Cetakan ke-23, Penerbit: Alfabeta, Bandung.

[31] Salimetrics,. (2014). Salivary Secretory IgA: Enzyme Immunoassy Kit. Salimetrics, LLC. 101 Innovation Blvd., Suit 302. Stat College, PA 16803, USA.

[32] H. W. Mueller-Wohlfahrt et al., "Terminology and classification of muscle injuries in sport: The Munich consensus statement," Br. J. Sports Med., vol. 47, no. 6, pp. 342-350, 2013.

[33] Tejero-Fernandez V., Membrilla-Mesa M., Galiano-Castillo N. \& Arroyo-Morales M. Immunological effects of massage after exercise: A systematic review Physical Therapy in Sport 16 (2) July 2014 with 103 Reads. Impact Factor: 1.65 DOI: 10.1016/j.ptsp.2014.07.001. Hal. 1. [PubMed] [Cross Ref]

[34] M. Listing et al., "The efficacy of classical massage on stress perception and cortisol following primary treatment of breast cancer," Arch. Womens. Ment. Health, vol. 13, no. 2, pp. $165-173,2010$.

[35] Moreira, A, Arsati, F, de Oliveira Lima-Arsati, YB, de Freitas, CG, and de Araújo, VC., (2011). Salivary Immunoglobulin A Responses in Professional Top-Level Futsal Players. Journal of Strength \& Conditioning Research: July 2011 - Volume 25 - Issue 7 - pp 1932-1936.

[36] Rosa Adriana Jarillo-Luna, Victor Rivera-Aguilar, Judith Pacheco-Yépez, Rigoberto Oros-Pantoja, Angel Miliar-García, Rafael Campos-Rodríguez., Nasal IgA secretion in a murine model of acute stress. The possible role of catecholamines. Journal of Neuroimmunology Volume 278, 15 January 2015, Pages 223-231
[37] L T MacKinnon ${ }^{1}$, dan D G Jenkins Decreased salivary immunoglobulins after intense interval exercise before and after training (1993 Jun;25(6):678-83) Med Sci Sports Exerc

[38] Robson PJ, Blannin AK, Walsh NP, Castell LM, Gleeson M. Effects of exercise intensity, duration and recovery on in vitro neutrophil function in male athletes. Int J Sports Med 20: $128-135,1999$.

[39] Peake JM. Exercise-induced alterations in neutrophil degranulation and respiratory burst activity: possible mechanisms of action. Exerc Immunol Rev 8: 49-100, 2002

[40] Nieman DC, Miller AR, Henson DA, Warren BJ, Gusewitch G, Johnson RL, Davis JM, Butterworth DE, Nehlsen-Cannarella SL. Effects of high- vs moderate-intensity exercise on natural killer cell activity. Med Sci Sports Exerc 25: 1126 -1134, 1993. doi:10.1249/ 00005768-199310000-00008

[41] Gleeson M, Bishop NC. The T cell and NK cell immune response to exercise. Ann Transplant 10: 43-48, 200548. (126). Walsh NP, Gleeson M, Shephard RJ, Gleeson M, Woods JA, Bishop NC, Fleshner M, Green C, Pedersen BK, Hoffman-Goetz L, Rogers CJ, Northoff H, Abbasi A, Simon P. Position statement. Part one: immune function and exercise. Exerc Immunol Rev 17: 6 -63, 2011.

[42] Bishop NC, Walker GJ, Gleeson M, Wallace FA, Hewitt CR. Human T lymphocyte migration towards the supernatants of human rhinovirus infected airway epithelial cells: influence of exercise and carbohydrate intake. Exerc Immunol Rev 15: 127-144, 2009

[43] Starkie RL, Angus DJ, Rolland J, Hargreaves M, Febbraio MA. Effect of prolonged, submaximal exercise and carbohydrate ingestion on monocyte intracellular cytokine production in humans. J Physiol 528: 647-655, 2000. doi:10.1111/j.1469-7793.2000.t01-1-00647.x.

[44] Steensberg A, Toft AD, Bruunsgaard H, Sandmand M, HalkjaerKristensen J, Pedersen BK. Strenuous exercise decreases the percentage of type $1 \mathrm{~T}$ cells in the circulation. J Appl Physiol (1985) 91: 1708 -1712, 2001.

[45] Pedersen BK, Rohde T, Ostrowski K. Recovery of the immune system after exercise. Acta Physiol Scand 162: 325-332, 1998. doi:10.1046/j. 1365-201X.1998.0325e.x

[46] Robson-Ansley PJ, Blannin A, Gleeson M. Elevated plasma interleukin-6 levels in trained male triathletes following an acute period of intense interval training. Eur J Appl Physiol 99: 353-360, 2007. doi:10. 1007/s00421-006-0354-y

[47] Verde T, Thomas S, Shephard RJ. Potential markers of heavy training in highly trained distance runners. Br J Sports Med 26: 167-175, 1992. doi:10.1136/bjsm.26.3.167.

[48] Halson SL, Lancaster GI, Jeukendrup AE, Gleeson M. Immunological responses to overreaching in cyclists. Med Sci Sports Exerc 35: $854 \quad-861,2003$. doi:10.1249/01.MSS.0000064964.80040.E9

[49] Robson-Ansley PJ, Blannin A, Gleeson M. Elevated plasma interleukin-6 levels in trained male triathletes following an acute period of intense interval training. Eur J Appl Physiol 99: 353-360, 2007. doi:10. 1007/s00421-006-0354-y.58. 124).

[50] Fahlman MM, Engels HJ. Mucosal IgA and URTI in 
American college football players: a year longitudinal study. Med Sci Sports Exerc 37: 374 -380, 2005. doi:10.1249/01.MSS.0000155432.67020.88

[51] Gleeson M, McDonald WA, Cripps AW, Pyne DB, Clancy RL, Fricker PA. The effect on immunity of long-term intensive training in elite swimmers. Clin Exp Immunol 102: 210 -216, 1995. doi:10.1111/j. 1365-2249.1995.tb06658.x.

[52] Mackinnon LT, Hooper S. Mucosal (secretory) immune system responses to exercise of varying intensity and during overtraining. Int J Sports Med 15, Suppl 3: S179 -S183, 1994. doi:10.1055/s-2007- 1021134

[53] Morgado JM, Rama L, Silva I, de Jesus Inácio M, Henriques A, Laranjeira P, Pedreiro S, Rosado F, Alves F, Gleeson M, Pais ML, Paiva A, Teixeira AM. Cytokine production by monocytes, neutrophils, and dendritic cells is hampered by long-term intensive training in elite swimmers. Eur J Appl Physiol 112: 471-482, 2012. doi:10.1007/s00421011-1966-4.

[54] Finberg M, Braham R, Goodman C, Gregory P, Peeling P. Effects of electrostimulation therapy on recovery from acute team-sport activity. Int J Sports Physiol Perform 8: 293-299, 2013. doi:10.1123/ijspp.8.3.293
[55] Fry RW, Grove JR, Morton AR, Zeroni PM, Gaudieri S, Keast D. Psychological and immunological correlates of acute overtraining. Br J Sports Med 28: 241-246, 1994. doi:10.1136/bjsm.28.4.241

[56] Gleeson M, McDonald WA, Cripps AW, Pyne DB, Clancy RL, Fricker PA. The effect on immunity of long-term intensive training in elite swimmers. Clin Exp Immunol 102: 210 -216, 1995. doi:10.1111/j. 1365-2249.1995.tb06658.x

[57] Mackinnon LT, Hooper SL, Jones S, Gordon RD, Bachmann AW. Hormonal, immunological, and hematological responses to intensified training in elite swimmers. Med Sci Sports Exerc 29: 1637-1645, 1997. doi:10.1097/00005768199712000-00014

[58] Gabriel HH, Urhausen A, Valet G, Heidelbach U, Kindermann W. Overtraining and immune system: a prospective longitudinal study in endurance athletes. Med Sci Sports Exerc 30: 1151-1157, 1998. doi:10. 1097/00005768-199807000-00021.

[59] Rowbottom DG, Keast D, Goodman C, Morton AR. The haematological, biochemical and immunological profile of athletes suffering from the overtraining syndrome. Eur $\mathrm{J}$ Appl Physiol Occup Physiol 70: 502-509, 1995. doi:10.1007/BF00634379 